\title{
Chapter 4 \\ Policy Coherence for Sustainable \\ Development in International Tax Matters: \\ A Way Forward for Donor Countries?
}

Sathi Meyer-Nandi

\subsection{Introduction}

\subsubsection{Background}

The Addis Ababa Action Agenda (AAAA) puts taxation distinctively into the spotlight of the Sustainable Development Goals (SDGs). The mobilization and effective use of domestic resources (DRM) are seen as vital to financing and achieving the SDGs. Efforts by developing countries to improve their DRM capabilities are supported by targeted international assistance (UN 2015, Action area II, A.).The rationale is to help developing countries ultimately help themselves-as more domestic resources gradually lead to less foreign aid dependency. More domestic resources in developing countries also lead to a more stable State, which is capable of providing basic public services, such as health care, infrastructure, and education. Accordingly, large amounts of public resources are allocated to DRM support, covering various areas to broaden and secure the tax base of developing countries. There is additional consensus that low-income countries are disproportionately affected by tax avoidance strategies of multinational corporations [a practice known as "Base Erosion and Profit Shifting" (BEPS)] and tax evasion through undeclared offshore accounts. Tackling BEPS and participating in the global transparency framework (hereafter referred to as "international tax matters") are hence of particular relevance for enhancing revenues in developing countries and a focus area of donor support with enhanced technical assistance [either bilaterally

All opinions expressed in the paper are those of the author in her private capacity.

S. Meyer-Nandi $(\bowtie)$

GIZ GmbH, Bonn, Germany

(C) The Author(s) 2021 
between donor and partner country or through supporting capacity building programs from international organizations ${ }^{1}$ (e.g., OECD, UN, World Bank, or IMF)].

To put the political commitment of donors into perspective, or even better, into numbers, 20 donor countries alone have explicitly declared to double their 2015 support for DRM of over USD215 million until 2020. The commitment amounts to over USD430 million by 2020 of gross disbursements for DRM support (ATI 2019, p. 12). These commitments for spending public money are not insignificant in scale but well justified if it constitutes the catalyst to create self-sufficiency. However, given this scale, enhanced policy coherence can go a long way, ensuring that public money is well spent.

\subsubsection{What Is Policy Coherence for Sustainable Development (PCSD)?}

PCSD requires a holistic evaluation of all national policies-including the tax policy-concerning their impact on the achievement of the SDGs for all stakeholders. Many countries consider PCSD as a critical means to manage potential trade-offs, promote synergies, and reduce inefficient spending. Hence, all countries explicitly agreed to incorporate the enhancement of PCSD as a focal point for implementing the 2030 Agenda [as inter alia enshrined in Target 17.14 of the AAAA and in Commitment 3 in the Addis Tax Initiative (ATI)].

This commitment ensures that aid spending is not "wasted" by competing policies as it presupposes that government considers development goals working toward all other national policies. The whole government, beyond foreign affairs, development ministries, and aid agencies, needs to be engaged in this endeavor to manage tensions and synergies between different sectoral, domestic, and international policies. Other relevant stakeholders such as civil society and private sector should ideally also be included in this dialogue.

One should bear in mind that PCSD does not prescribe full coherence, an impossible endeavor anyway. Nor, does the rule dictate that development objectives trump every other national policy. It should rather be seen as a mechanism to facilitate dialogue for informed weighing and balancing of different policy decisions with the goal that public money is spent prudently.

\footnotetext{
${ }^{1}$ See, for instance, the OECD's technical assistance projects on international tax issues: OECD (2019).
} 


\subsubsection{Why Is PCSD so Important in the Area of International Tax Matters?}

PCSD in international tax matters helps to ensure that the vast amount of resources allocated to helping developing countries mobilize more revenues are supported and not de facto cancelled out by national tax policy choices of donor countries. Some choices on tax policy and tax administration of donor countries create strong interactions with these international tax matters in developing countries (IMF 2014 , p. 1). These choices have ramifications on the tax base in developing countries as well as the cooperation modalities between the tax administrations. This is why technical assistance alone should not be the only means to increase DRM in developing countries. Donor countries need to review their own national tax policy and administrative practices to better identify negative or positive spillovers on the tax base of developing countries.

\subsubsection{Rational and Structure of the Chapter}

In practice, the genuine implementation of PCSD in the area of international tax matters has some room for improvement. Though civil servants agree that giving with one hand but taking with the other is inefficient and that seeking synergies between different policy areas is a good thing to do, the holistic dialogue between all relevant ministries and stakeholders is often missing.

Different ministries and stakeholders speak different languages, which can be a big obstacle for a holistic dialogue particularly in such a technical subject matter, such as international taxation. Additionally, the different stakeholders have different understandings on what benefits sustainable development. This is why PCSD is often lost in translation. It stays a concept which-despite being internationally endorsed-constitutes the neglected hot potato civil servants do not want to touch.

What is however often forgotten is that PCSD is not a zero-sum game. Adjusting policies more toward development objectives can also be beneficial for other policy goals. Accordingly, having mechanism in place for inclusive dialogue among all stakeholders on international tax matters can bring useful ideas, which go beyond "do no harm to developing countries" but can also be beneficial for the national industry of the donor country.

Against this backdrop, this chapter is devoted to potential measures of donor countries to better align their tax policy with their development effort in the area of international tax. These measures aim at raising the revenues in developing countries while also contributing to a positive investment climate. Accordingly, Part II will primarily focus on establishing a policy for tax treaties with developing countries, which enhance source taxation and tax certainty. Part III includes domestic measures to enhance transparency in developing countries which go beyond the internationally agreed standards on exchange of information. Part IV elaborates on mechanisms to 
enhance cooperation between the tax administration of the donor and partner country, to provide better skill transfer while boosting tax certainty for companies.

\subsection{Donor's Tax Treaty Policy Toward Developing Countries}

\subsubsection{Background}

In principle the rationale of Double Tax Treaties (DTTs) is to increase tax certainty and avoid double taxation for cross-border activities of taxpayers. They foster bigger certainty as they set limits to the taxation of cross-border investments through allocating taxing rights between the foreign direct investment (FDI) recipient country-generally in fiscal terms referred to as the source country-and the residence country of the investor. DTTs are responsible for mitigating double taxation by "harmonizing tax definitions, defining taxable bases, assigning taxing jurisdictions, and indicating the mechanisms to be used to remove double taxation when it arises" (Baker 2012, p. 2 referring to UNCTAD 2011).

However, an important feature of DTTs is that they have a bias in favor of the residence state. They tend to shift taxing powers from the source state to the residence state. This bias does not have to be problematic if two treaty partners are involved with largely symmetrical investment pattern (Braun and Zahler 2017, p. 2). However when two countries have an asymmetrical investment position-as is generally the case between developing and industrialized country-this shift in taxing powers implies a significant loss of tax base for the source country (Rixen and Schwarz 2009).

Developing countries are mainly net capital importing countries, with the capital streaming predominantly from industrialized countries into their economy and capital income flowing the other way around. Hence, the limitation on source country taxing powers to the benefit of the residence country brings about the disadvantage of revenue foregone from restricted source country taxation next to the cost of treaty negotiation and administration (Keen and Mullins 2017, pp. 11-41).

Hence, the question is does the DTT realize sufficient net gains from increased FDI to neutralize the revenue losses? The answer is one does not know. Conclusive empirical evidence on the investment effects of treaties is missing, since identifying causality (between the conclusion of the treaty and the resulting increased FDI) is inherently problematic (Hearson 2018). ${ }^{2}$ However what has become increasingly prevalent and perceived as problematic is the issue of developing countries losing tax revenues due to the conclusion of tax treaties.

\footnotetext{
${ }^{2}$ Also Appendix V of the IMF (2014) paper provides an analysis of different studies undertaken on the correlation of treaties and the increase of FDI.
} 
Additionally, next to the reduction of tax revenues due to the limitation of source taxation, DTTs also limit the policy space of developing countries to legislate feasible measures against BEPS. Due to administrative capacity restraints, potential responses against base erosion and profit shifting, which resulted out of the OECD BEPS project, might not be administrable for some developing countries.

For instance, excessive use of deductible payments to foreign affiliated companies in form of interest, service charges, insurance premiums, management fees, and royalties has been identified as one of the key base erosion causes in developing countries (G20 2014; Oguttu 2017, pp. 35-36). Although not being officially addressed in the BEPS Project, withholding taxes have often been considered the most suitable means for developing countries against this tax avoidance technique (IMF 2014, pp. 33-34; UN Report 2013, p. 11).

Withholding taxes do not compensate entirely the loss of income stripping since mostly the withholding tax rates are lower than the corporate income tax rate. They should also not be excessive, since they are levied on gross basis and can increase the cost of capital. However, they constitute a workable backstop and tax base protection mechanism, which should not be neutralized via the tax treaty (Shay 2017, pp. 65-66).

\subsubsection{Domestic Measures of Donor Countries}

\subsubsection{Create a Policy for Tax Treaties with Developing Countries}

When DRM is a priority area of donor countries, it is desirable that their tax treaty policy toward their partner countries reflects this aim-if coherence is an aspiration. Accordingly, donor countries should create a formal policy; they openly pledge to adhere to when entering into tax treaty negotiations with developing countries and when reviewing existing ones.

When designing the policy, it is important to engage the whole government, significant players in the economy, civil society, academia, and developing countries which constitute a particular focus of the donor's aid program. Accordingly, the ministry of finance, treasury-or whoever is responsible for tax treaties-should engage foreign affairs, the development ministry, and aid agency in the dialogue. Other relevant stakeholders such as civil society, academia, and the private sector should share their viewpoints on how the policy should look like and the expected effect on DRM and the investment climate.

The policy should go beyond a mere communication of a country's willingness to accept broader permanent establishment concepts, higher withholding tax rates at source, parts of the UN Model, as well as anti-abuse measures for tax treaties with 
developing countries which receive aid. ${ }^{3}$ In a holistic forum of communication among all relevant stakeholders, the tax policy strategy should have the aim to provide for higher source-based taxation, foster tax certainty, and avoid double taxation through fully crediting the higher source-based taxation and stronger cooperation between both tax administrations.

Accordingly, the box below depicts contemplations regarding source taxation, tax certainty, and the avoidance of double taxation, which should be considered by donor countries in their endeavor to create a tax treaty policy toward developing countries.

\section{More Source Taxation}

-Tax treaty should be customized to the domestic legal framework of the developing country, with the aim to make sure that the treaty uphelds domestic source taxation to the biggest extent possible.

- As a practical anti-base erosion measure, when domestic law provides withholding taxes on deductible payments, such as on services fees and insurance premiums, the treaty should not inhibit this fiscal space. More nuanced withholding tax policy can rather be adressed via domestic law (supported by technical assistance of donor countries) and not through restrictions on treaty level.

-Customize your treaty to the specific circumstances of the country. For instance, if the country often provides tax holidays, including higher dividend withholding taxes, which only apply, when the distributed income has been subject to a tax holiday, could be an option. Also tax sparing provisions should be considered when appropirate.

-Are domestic law provisions, such as the permanent establishement definitions, outdated and hence result in uncertainty in their application, especially in connection with their interplay with the tax treaty? In such cases technical assistance could be provided to update domestic law to better reflect international standards.

-What is the experience of business regarding the tax framework of the country and its administration? What were the main challenges, which could be adressed via the treaty to provide more tax certainty?

- Strenghten the cooperation modalities between both tax administrations through enhanced cooperation arrangements (establishing bilateral safe harbours, bilateral APA programmes, enhanced knowledge sharing, simultansous tax audits, etc.).

\section{No Double Taxation}

-Donor countries should try to provide a full tax credit on the higher source taxation, so that it does not have a negative effect on the investment climate.

-Donors need to calculate whether the resulting tax expenditure on their side is sustainable and maybe need to coordinate between ministry of finance and the development ministry to credit some of these expenses to the development budget if necessary.

\footnotetext{
${ }^{3}$ These communications are mostly directed at countries which appear on the Development Assistance Committee (DAC) List as countries and territories eligible to receive official development assistance (ODA). The list consists of all low- and middle-income countries based on World Bank data on gross national income per capita.
} 


\subsection{Transparency}

\subsubsection{Background}

The late US Justice Louis Brandeis famously stated, "sunlight is the best disinfectant." Correspondingly, an important mechanism for the elimination of tax avoidance and evasion is transparency. Transparency through the exchange of information on a global scale helps to avoid information asymmetries though enhancing a more transparent global tax footprint. Particularly for developing countries, it constitutes an important tool to inhibit the loss of revenues from assets held offshore or misrepresented cross-border activities. The G20 and the OECD's Global Forum on Transparency and Exchange of Information for Tax Purposes (the Global Forum) were the driving force to improve transparency through setting global standards for information sharing around the world. The OECD has developed two complementary international standards: the Exchange of Information on Request (EOIR) and the Automatic Exchange of Financial Account Information (AEOI).

- The EOIR standard calls for exchange of information to the widest extent possible. Subject to having the respective legal basis in place, information that is "foreseeably relevant" for tax purposes is made available and accessible between tax authorities. The exchangeable information includes the identity of the beneficial owners of companies and other legal entities; arrangements such as partnerships and trusts; accounting information; and bank account information. ${ }^{4}$

- AEOI standard takes the cooperation a step further. It requires the systematic and periodic transmission of "bulk" taxpayer information by the source country to the residence country in a common reporting format or standard. Local banks and financial institutions of participating countries are required to obtain information on financial accounts, which they make available to the local tax authorities; they, in turn, provide that information on an automatic basis to other countries in a standardized format (without the need for sending a specific request) (OECD 2014b).

The OECD's Global Forum provides customized technical assistance programs to help developing countries implement both standards to counter tax evasion. The technical assistance is offered in various forms delivered on-site and off-site and in collaboration with other partners (e.g., other international organizations, development banks, or donor countries). The assistance is targeted to establishing the required legal framework (domestic law and treaties) and the practical organizational arrangements to be able to make use of the international transparency standards. ${ }^{5}$

\footnotetext{
${ }^{4}$ For more information on the EOIR, please consult OECD (2016).

${ }^{5}$ More information on the different technical assistance programs can be found in the OECD's work on tax and development under OECD (2019).
} 


\subsubsection{Domestic Measures of Donor Countries}

\subsubsection{Review the Domestic Transparency Framework}

The first measure of donor countries is to make sure that their network of exchange relationships covers all relevant developing countries (at least those developing countries, which are recipients of aid programs by the donor). The legal framework in place can either be based on bilateral instruments [DTTs or Tax Information Exchange Agreements (TIEA)] or multilateral mechanisms, such as the Mutual Administrative Assistance Convention. Hence, a gap analysis could first be conducted to see whether the coverage is sufficient and if not how to close these gaps in the most resource efficient way for the developing country.

Additionally, detecting hidden offshore wealth through exchange of information requires the availability of relevant information. This is why, also from a policy coherence perspective, it is vital that donor countries have domestically all required information available. The identity of legal and beneficial owners of bank account, relevant entities, and arrangements, as well as the accounting information for these entities, needs to be at disposal. It requires effective enforcement provisions to make sure that those responsible for collecting this information do the relevant due diligence. The accuracy of the information and the compliance need to be monitored with penalties in place, which sufficiently deter non-compliance.

\subsubsection{Disclosing Aggregate Data}

It will still take time, and a multitude of assistance before AEOI becomes viable for developing countries. Until then, the EOIR will be the instrument to obtain crossborder information. The disadvantage of EOIR is that tax authorities need to be aware of a tax evader and link the evasion to a specific jurisdiction to request the missing information from this jurisdiction. However, obtaining this preliminary evidence when one has limited resources available can be difficult. This is where the sharing of de-identified aggregate data about financial accounts held in donor countries can be beneficial. Such information could be published each year depicting totals by country of origin held in the donor country (Knobel and Meinzer 2017, pp. 37-39).

To date, many countries have spontaneously shared aggregate data with their treaty partners on various types of income, such as the existence and amount of foreign-owned accounts in their jurisdiction. The Global Forum stated that G20 and other developed countries may consider spontaneously sharing aggregate data with a specific developing country. The purpose of this would be:

to build awareness of AEOI, to demonstrate possible revenue benefits and increase the prioritisation of AEOI, and to obtain political commitment to AEOI. (G20 2014, p. 22)

One step further to the spontaneous sharing of aggregated data with treaty partners is to simply publish de-identified aggregated information about accounts 
held in the country (as Australia and Switzerland are already doing). ${ }^{6}$ Given that only totals by country of origin would be published, no confidentiality rules would be breached. The big advantage of such measure is that it allows both countries not constituting treaty partners as well as civil society to find out basic information about their residents' holdings abroad. Such a measure helps developing countries to allocate their scarce resources more effectively. It gives tax administrations in developing countries directly the information in which countries their residents held the biggest amount of offshore assets. This is helpful to channel the attention of a tax authority to a certain jurisdiction to request information from.

It can also increase political pressure on government in developing countries to more effectively fight against tax evasion, as it provides more transparency on the scale of offshore assets. The increased pressure on politicians can be especially beneficial in developing countries, in which the political or economic elite opposes the introduction of AEOI, due to their own exposure to undeclared offshore money. Transparency in general also helps the population of a developing country to estimate whether the tax rules and administration in their country are functional or need revision.

\subsection{International Cooperation/Administrative Assistance}

\subsubsection{Background}

Base erosion through abusive transfer pricing is considered a major risk for developing countries. The limited capacity and the lack of information in order to apply adequate transfer pricing rules have been identified as a key BEPS issue in developing countries (G20 2014, p. 10). Many resources are allocated to strengthening transfer pricing capacity. For instance, the Platform for Collaboration on Tax and Tax Inspectors Without Borders all have activities in place to improve the transfer pricing regimes in developing countries and to enhance their audit capacity. ${ }^{7}$ However, the World Bank pointed out that building transfer pricing expertise is not a short-term endeavor and that country experience suggests that institution building for effective transfer pricing audit skills takes a minimum of 3-5 years (Cooper et al. 2016, p. xix).

Next to the base erosion in developing countries, also tax uncertainty on behalf of business is exacerbated by the tax administration's limited experience in transfer pricing. This often leads to highly unpredictable tax outcomes, which have a negative impact on the investment climate in the country.

More agile mechanisms for collaboration between tax administrations of donor and developing country can play an important role to firstly rectify the information

\footnotetext{
${ }^{6}$ For more information on Australia's amended bill, see Tax Justice Network (2016).

${ }^{7}$ For more information see the progress report of the Platform For Collaboration on Tax (2019).
} 
asymmetry of some auditors in developing countries, increase industry-specific know-how, and transfer pricing (TP) capacity. At the same time, tax certainty can be boosted for businesses of the donor country, which want to invest in the developing country. The legal basis for this enhanced cooperation can already be found in most current tax treaties - if they include the international standard of exchange of information, TIEAs or the Mutual Administrative Assistance Convention.

\subsubsection{Domestic Measures of Donor Countries}

While ensuring that all exchanges of information are in accordance with the provisions of an effective bilateral or multilateral tax convention, agile and enhanced modalities for cooperation between tax administrations should be created. In the process of designing these modalities, again the whole government, significant players in the economy, civil society, academia, and developing countries which constitute a particular focus of the donor's aid program should be included in the design process. In an inclusive dialogue, these modalities should feed into the aim to enhance DRM in developing countries and increase technical capacity as well as tax certainty for businesses for a better investment climate. Some modalities are suggested below.

\subsubsection{Specific Working Agreements Between Tax Administrations Including Joint Tax Audits and Safe Harbors}

Donor countries could conclude a special working agreement or memorandum of understanding (MoU) with the tax administration in a developing country treaty partner, setting forth the details for enhanced cooperation and discussion (MeyerNandi 2018, p. 54). Donor countries could agree to periodically share generic industry knowledge (e.g., information concerning whole economic sectors, such as the oil or pharmaceutical industry, the banking sector, etc.) if this is helpful for the partner country to better understand value chains in specific sectors. ${ }^{8}$ It should enable a platform to intensify and facilitate practical discussion on transfer pricing methods or comparability analysis between the tax administration of the developing country and the donor. To avoid disputes from arising, joint tax audit programs can be created, to jointly determine the facts and circumstances of cross-border cases.

These MoUs can also include bilateral safe harbors acceptable for both tax administrations. A safe harbor is a simplified regime that applies to a defined category of taxpayers or transactions. It enables eligible taxpayers to establish transfer prices by applying, for instance, a simplified transfer pricing approach

\footnotetext{
${ }^{8}$ Para. 6.1 OECD Model: Commentary on Article 26 (2014).
} 
provided by the tax administration. ${ }^{9}$ In the case of bilateral safe harbors, two or more $^{10}$ tax administrations by means of competent authority agreements define together a category of taxpayer and/or transactions and establish pricing parameters (i.e., the safe harbor) that would be acceptable to both countries. ${ }^{11}$ This bilateral agreement largely reduces the risk of potential double taxation or double non-taxation, which could arise under unilateral safe harbors. The OECD created a sample agreement for common categories of transfer pricing cases involving low-risk distribution functions, low-risk manufacturing functions, and low-risk research and development $(\mathrm{R} \& \mathrm{D})$ functions. ${ }^{12}$ These sample safe harbors can be used as a starting point and modified to the specific country context and relationship between donor and developing country.

The "development-friendly" safe harbors should be established in close collaboration with business and civil society for specific transactions and functions, particularly relevant in the country context of the developing country. Ultimately, the rational of the bilateral safe harbors should be to provide a means of protecting the local tax base in the developing country in common transfer pricing fact patterns without a burdensome enforcement effort. At the same time, they need to reduce the compliance cost of the taxpayer and increase tax certainty.

\subsubsection{Bilateral Advanced Pricing Agreements (APAs)}

Bilateral APA programs between donor and developing countries could be a practical solution to enhance tax certainty for business while also speeding up the capacity building process of tax administrations (Meyer-Nandi 2018, pp. 57-59). Additionally, having the donor's tax administration present would provide more checks and balances during the negotiations and neutralize the knowledge asymmetry potentially present in unilateral APA negotiations only between multinational enterprises and a developing country tax administration. These bilateral negotiations, interactions, and cooperation between two tax administrations alleviate double taxation of the multinational taxpayer's income. It also provides an avenue for countries to quickly get up to speed on international practices while defending their tax base and increasing bilateral cooperation. ${ }^{13}$

In the course of the negotiation, the two tax administrations obviously have an incentive to opt each for a point of view that maximizes their revenue collection. In bilateral APAs with developing countries, a policy could be adopted by the donor to be more beneficial to developing countries. Tax administrations from the donor

\footnotetext{
${ }^{9}$ Sec. E.2. OECD Transfer Pricing Guidelines (2017).

${ }^{10}$ Then the safe harbor is called "multilateral safe harbor."

${ }^{11}$ Para. 4.117., OECD Transfer Pricing Guidelines (2017).

${ }^{12}$ Annex I to Chapter IV, OECD Transfer Pricing Guidelines (2017).

${ }^{13}$ More information on the advantages of bilateral APAs in comparison to unilateral ones can be found in Cooper et al. (2016, p. 321).
} 
could, for instance, heed so-called location-specific advantages in the allocation of profit to attribute a bigger share of profit to the developing country. ${ }^{14}$

\subsection{Concluding Words}

The aim of this chapter is to provide civil servants with some food for thought how to improve PCSD in the area of international tax matters and to demonstrate that PCSD is not a zero-sum game. Adjusting the tax policy of a donor country more toward development objectives can foster DRM in developing countries while also being beneficial for the industry of the donor country itself. The aspiration of the author is that donor countries will create the necessary platform for an inclusive dialogue on this neglected topic. Engaging all relevant ministries and stakeholders (business, civil society, and academia) to work on a domestic strategy how to better increase PCSD in the area of international tax matters can bring new ideas, promote informed decision making, and aid effectiveness. Having an inclusive dialogue on such a technical subject matter is not an easy endeavor indeed. However, it is necessary to start it, as it does not only affect the taxes in developing countries but also the taxpayers in donor countries. The taxpayer in the donor country is the financier of civil servants and their policies. Against this background, civil servants owe a genuine dialogue on PCSD in the area of international tax matters to their taxpayers, as it improves prudent public spending.

\section{References}

\section{G20 Sources}

G20. (2014). Two-part report to G20 developing working group on the impact of BEPS in low income countries (p. 43). Retrieved from http://www.oecd.org/tax/tax-global/report-to-g20dwg-on-the-impact-of-beps-in-low-income-countries.pdf

\section{OECD Sources}

OECD. (2014a). Model tax convention on income and on capital: Condensed version 2014. Paris: OECD. https://doi.org/10.1787/mtc_cond-2014-en

\footnotetext{
${ }^{14}$ For more information on location-specific advantages, see Sec. B.8.11.5., UN Practical Manual on Transfer Pricing for Developing Countries (2017); a similar example is also described on India in Sec. B.8.1.14. and Cooper et al. (2016, p. 218).
} 
OECD. (2014b). Standard for automatic exchange of financial account information in tax matters. Paris: OECD. Retrieved from https://doi.org/10.1787/9789264216525-en

OECD. (2016). Exchange of information on request-Handbook for peer reviews 2016-2020. Retrieved from https://www.oecd.org/tax/transparency/global-forum-handbook-2016.pdf

OECD. (2017). OECD transfer pricing guidelines for multinational enterprises and tax administrations 2017. Paris: OECD. Retrieved from https://doi.org/10.1787/tpg-2017-en

OECD. (2019). OECD work on tax and development-2018-2019. Retrieved from http://www. oecd.org/tax/tax-global/brochure-oecd-work-on-tax-and-development.pdf

\section{UN Sources}

UN. (2015). Addis Ababa Action Agenda of the third international conference on financing for development (Addis Ababa Action Agenda). A/RES/69/313.

UN. (2017). Practical manual on transfer pricing for developing countries. New York: UN.

UN Report. (2013, January 28-29). Group meetings on "Capacity building on tax treaty negotiation and administration”. Rome.

\section{Other Sources from International Organizations}

ATI. (2019). ATI monitoring report 2017. Retrieved from https://www.addistaxinitiative.net/sites/ default/files/resources/2019-ATI-Monitoring-Report-2017.pdf

IMF. (2014). Spillovers in international corporate taxation. Washington, DC: International Monetary Fund. Retrieved from http://www.imf.org/external/np/pp/eng/2014/050914.pdf

Platform For Collaboration on Tax. (2019). PCT progress report 2018-2019. Retrieved from http:// documents.worldbank.org/curated/en/702411559936259607/pdf/Platform-for-Collaborationon-Tax-PCT-Progress-Report-2018-2019.pdf

UNCTAD. (2011). World investment report. Non-equity modes of international production and development. New York: United Nations.

\section{Journals and Other Articles}

Baker, P. (2012). An analysis of double tax treaties and their effect on foreign direct investment. Retrieved from http://www2.warwick.ac.uk/fac/soc/economics/news_events/conferences/ peuk12/paul_1_baker_dtts_on_fdi_23_may_2012.pdf

Braun, J., \& Zahler, M. (2017). The true art of the tax deal: Evidence on aid flows and bilateral double tax agreements. Discussion Paper No. 17-011, Zentrum für Europäische Wirtschaftsforschung GmbH. Retrieved from http://ftp.zew.de/pub/zew-docs/dp/dp17011.pdf

Cooper, J., Fox, R., Loeprick, J., \& Mohindra, K. (2016). Transfer pricing and developing economies $-A$ handbook for policy makers and practitioners. Washington, DC: World Bank Group.

Hearson, M. (2018). WHEN do developing countries negotiate away their corporate tax base? Journal of International Development, 30, 233-255. 
Keen, M., \& Mullins, P. (2017). International corporate taxation and the extractive industries: Principles, practice, problems. In P. Daniel, M. Keen, A. Swistak, \& V. Thuronyi (Eds.), International taxation and the extractive industries. London: Routledge.

Knobel, A., \& Meinzer, M. (2017). Delivering a level playing field for offshore bank accountsWhat the new OECD/Global Forum peer review on automatic information exchange must not miss. Tax Justice Network. Retrieved from https://www.taxjustice.net/wp-content/uploads/ 2013/04/TJN_AIE_ToR_Mar-1-2017.pdf

Meyer-Nandi, S. (2018). Swiss policy coherence in international taxation: Global trends in AEOI and BEPS in development assistance and a Swiss way forward (p. 54). Retrieved September 28, 2019, from https://www.shareweb.ch/site/Development-Policy/Documents/ formAttachments/20181005_DEZA-Final_WorkingPaper_corrected.pdf

Oguttu, W. (2017). Tax base erosion and profit shifting in Africa-Part 2: A critique of some priority OECD actions from an African perspective. Working Paper 65, International Centre for Tax and Development.

Rixen, T., \& Schwarz, P. (2009). Bargaining over the avoidance of double taxation: Evidence from German tax treaties. Finanzarchiv/Public Finance Analysis, 65(4), 442-471.

Shay, S. E. (2017). An overview of transfer pricing in extractive industries. In P. Daniel, M. Keen, A. Swistak, \& V. Thuronyi (Eds.), International taxation and the extractive industries. London: Routledge.

Tax Justice Network. (2016). Australia passes new information sharing provision. Retrieved from http://www.taxjustice.net/2016/02/24/15031/

Open Access This chapter is licensed under the terms of the Creative Commons Attribution 4.0 International License (http://creativecommons.org/licenses/by/4.0/), which permits use, sharing, adaptation, distribution and reproduction in any medium or format, as long as you give appropriate credit to the original author(s) and the source, provide a link to the Creative Commons license and indicate if changes were made.

The images or other third party material in this chapter are included in the chapter's Creative Commons license, unless indicated otherwise in a credit line to the material. If material is not included in the chapter's Creative Commons license and your intended use is not permitted by statutory regulation or exceeds the permitted use, you will need to obtain permission directly from the copyright holder.

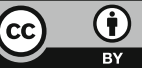

